\title{
COPYRIGHT TRANSFER AGREEMENT
}

The Authors submitting a manuscript do so on the understanding that if accepted for publication, copyright of the article shall be assigned to Bulletin of Chemical Reaction Engineering \& Catalysis and Department of Chemical Engineering Diponegoro University as publisher of the journal.

Copyright encompasses exclusive rights to reproduce and deliver the article in all form and media, including reprints, photographs, microfilms and any other similar reproductions, as well as translations. The reproduction of any part of this journal, its storage in databases and its transmission by any form or media, such as electronic, electrostatic and mechanical copies, photocopies, recordings, magnetic media, etc., will be allowed only with a written permission from Bulletin of Chemical Reaction Engineering \& Catalysis and Department of Chemical Engineering Diponegoro University.

Bulletin of Chemical Reaction Engineering \& Catalysis, Department of Chemical Engineering Diponegoro University, Editors, and International Advisory Editorial Board make every effort to ensure that no wrong or misleading data, opinions or statements be published in the journal. In any way, the contents of the articles and advertisements published in the Bulletin of Chemical Reaction Engineering $\&$ Catalysis (BCREC) are sole and exclusive responsibility of their respective authors and advertisers.

The Copyright Transfer Form can be downloaded at BCREC website :

(http://bcrec.undip.ac.id/copyright-transfer-agreement)

The copyright form should be signed originally and send to the Editorial Office in the form of original mail, scanned document, or fax to:

Assoc. Prof. Dr. I. ISTADI (Editor-in-Chief)

Editorial Office of Bulletin of Chemical Reaction Engineering \& Catalysis

Department of Chemical Engineering, Diponegoro University

Jl. Prof. Soedarto, Kampus UNDIP Tembalang, Semarang, Central Java, Indonesia

50275

Telp.: +62-24-7460058, Fax.: +62-24-76480675

E-mail: bcrec@undip.ac.id 


\section{BULLETIN OF CHEMICAL REACTION ENGINEERING \& CATALYSIS ISSN 1978-2993 (http://bcrec.undip.ac.id)}

\section{COPYRIGHT TRANSFER AGREEMENT FORM}

Name of Principal Authors:

Address of Principal Authors:

Tel:

Fax:

E-mail:

Author(s) Name:

Manuscript Title:

Date Received

1. I/We submit to the Bulletin of Chemical Reaction Engineering \& Catalysis the above manuscript. I/We certify that the work reported here has not been published before and contains no materials the publication of which would violate any copyright or other personal or proprietary right of any person or entity.

2. I/We hereby agree to transfer to Department of Chemical Engineering UNDIP the copyright of the above - named manuscript. I/We reserve the following: (1) All proprietary rights other than copyright such as patent rights. (2) The right to use all or part of this article in future works of our own such as in books and lectures.

(When there is more than one author, only one signature will suffice.)

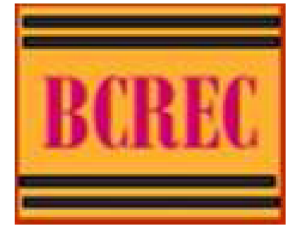

http://bcrec.undip.ac.id/copyright-transfer-agreement 